The 'Alids 
For Kaspar and Samuel 


\section{The 'Alids}

The First Family of Islam, 750-1200

\section{Teresa Bernheimer}


(C) Teresa Bernheimer, 2013

Edinburgh University Press Ltd

22 George Square, Edinburgh EH8 9LF

www.euppublishing.com

Typeset in Times Beyrut Roman by

3btype.com, and

printed and bound in Great Britain by

CPI Group (UK) Ltd, Croydon CR0 4YY

A CIP record for this book is available from the British Library

ISBN 9780748638475 (hardback)

ISBN 9780748638482 (webready PDF)

ISBN 9780748682959 (epub)

The right of Teresa Bernheimer to be identified as author of this work has been asserted in accordance with the Copyright, Designs and Patents Act 1988. 